\title{
Length-weight relationship and growth parameters of moonfish Mene maculata (Bloch and Schneider, 1801) from Karnataka Coast, India
}

\author{
DIVYA VISWAMBHARAN ${ }^{1}$, PRATIBHA ROHIT ${ }^{1}$, K. K. JOSHI ${ }^{2}$, SUJITHA THOMAS ${ }^{1}$, \\ LATHA SHENOY ${ }^{3}$ AND A. K. JAISWAR ${ }^{3}$ \\ ${ }^{1}$ Research Centre of ICAR-Central Marine Fisheries Research Institute, Mangalore - 575 001, Karnataka, India \\ ${ }^{2}$ ICAR-Central Marine Fisheries Research Institute, Ernakulam North P. O., Kochi - 682 018, Kerala, India \\ ${ }^{3}$ ICAR-Central Institute of Fisheries Education, Panch Marg, Off Yari Road, Versova, Andheri (W), Mumbai - 400061 \\ Maharashtra, India \\ e-mail:divyaarinu@gmail.com
}

\section{ABSTRACT}

\begin{abstract}
The present study aimed to elucidate the length-weight relationship and growth parameters of the moonfish Mene maculata (Bloch and Schneider, 1801) along the Karnataka Coast. The species showed positive allometric growth with pooled 'b' value of 3.390 which is significantly greater than $3(p<0.05)$ level. The "b" values of males $(3.316)$ and females $(3.440)$ showed significant difference from that of the indeterminates (2.90). The annual growth parameters estimated for moonfish off Karnataka Coast were: $\mathrm{L}_{\infty}=29.1 \mathrm{~cm}$ and $\mathrm{K}=1.014 \mathrm{yr}^{-1}$.
\end{abstract}

Keywords: Growth parameter, Karnataka Coast, Length-weight relationship, Mene maculata, Moonfish

Mene maculata (Bloch and Schneider, 1801) (Fig. 1) commonly known as moonfish forms a minor fishery along the Karnataka Coast of India. The fish is usually landed as a bycatch in the trawl fishery and is seldom used for domestic consumption due to insignificant catch which is mostly converted to fish meal. However, with increased operation of bull trawls/pair trawls and adoption of light fishing by purse seine, the catch of moonfish registered a significant increase during 2014-15. Consequent to this development of increased landings, a good domestic market emerged and the larger sized fishes fetch a good price. Though, the occurrence of moonfish was reported along the Indian Coast (Talwar and Kacker, 1984; Kapoor et al., 2002; Rajan et al., 2011), very little study has

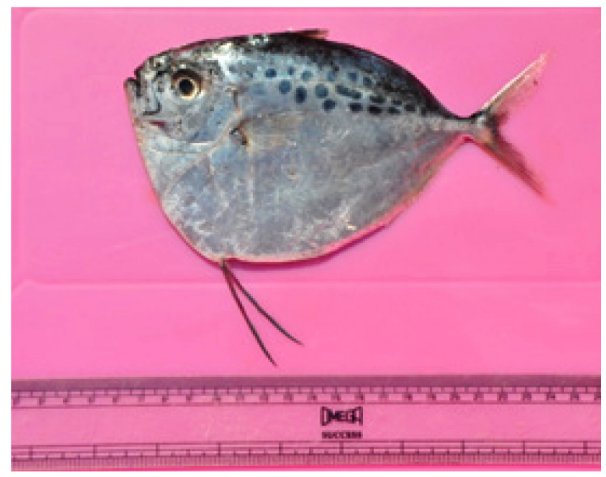

Fig. 1. Moonfish Mene maculata (Bloch and Schneider, 1801) been carried out on the growth of this species. Hence, a preliminary study was taken up to elucidate the lengthweight relationship as well as to estimate the growth parameters of moonfish landed along the Karnataka Coast.

Fish samples were collected every month from the mechanised fishing vessels landed at Mangaluru and Malpe fishing harbours in Karnataka from December 2015 to May 2017. The total length (TL, to the nearest $\mathrm{mm}$ ) from the tip of snout to the tip of upper caudal lobe and wet body weight (W, to the nearest $0.1 \mathrm{~g}$ ) of the sampled fishes were recorded. A total of 339 specimens with length ranging from 6.1 to $25.5 \mathrm{~cm}$ were classified on the basis of sex. There were 153 females, 105 males and 81 indeterminates.

The length-weight relationship was calculated using the formula (Le Cren, 1951):

$$
\mathrm{W}=\mathrm{a} \mathrm{L^{b }}
$$

where, $\mathrm{W}=$ body weight $(\mathrm{g}), \mathrm{L}=$ total length $(\mathrm{cm})$; ' $a$ ' is a coefficient allied to body and ' $b$ ' is an exponent signifying isometric growth when equal to 3 (Edwards, 1976). The same can be written in the logarithmic form as: $\ln \mathrm{W}=\ln \mathrm{a}+\mathrm{b} \ln \mathrm{L}$.

The constants ' $a$ ' and ' $b$ ' were derived by the method of linear least squares. The equations derived separately for males, females and indeterminates were compared for 
significant difference between regression coefficients (b) and intercepts (a) using Analysis of covariance following Snedecor and Cochran (1967). The t-test (Snedecor and Cochran, 1967) was done to check whether the regression coefficients (b) varied significantly from the isometric value of 3 .

For estimation of growth parameters, length data collected from trawlers were used. Samples from trawlers had length ranging from 61 to $255 \mathrm{~mm}$ (Fig. 2). Data was available for all months except June and July 2016, when a fishing ban existed along the Karnataka Coast. Further, during August 2016, severe rough weather conditions continued and only a few samples were collected from trawlers. The growth parameters of the moonfish population landed along the Karnataka Coast was estimated using the measurements of 1668 fishes collected during the study period. The length measurements were distributed into $5 \mathrm{~mm}$ class intervals. The size-frequencies were raised to the sampling days catch and then subsequently to the monthly catch. The preliminary estimate of growth parameter, $\mathrm{L}_{\infty}$ was estimated by the modified Wetherall plot in FiSAT software (Gayanilo et al., 1996). Automatic search routine and response surface were run to obtain the best $\mathrm{L}_{\infty}$ and $\mathrm{K}$ values. However due to poor goodness of fit, size frequency were delineated using Bhattacharya's method and modes of each cohort were linked and growth parameters were estimated by Gulland and Holt plot (Gulland and Holt, 1959). The corrections for gear selectivity were done using the selection factor $\left(\mathrm{L}_{50}=13.90\right.$ and $\left.\mathrm{L}_{75}=14.35 \mathrm{~cm}\right)$ and were used to re-estimate the length-frequencies (Mohamed and Rao, 1997) and finally the growth parameters were estimated using Gulland and Holt plot. The classical von Bertalanffy growth function (VBGF) (Sparre and Venema, 1998) was fitted to obtain the length of fish at different age using the following formula:

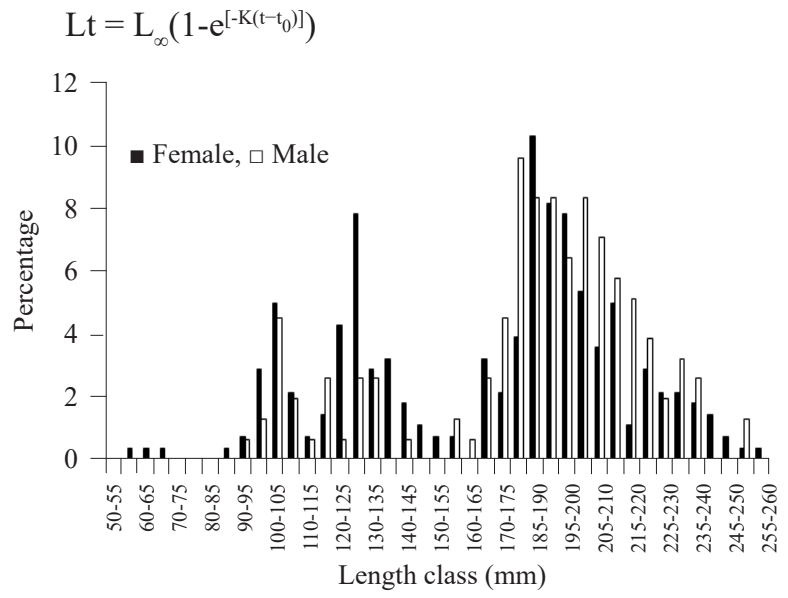

Fig. 2. Graph showing the percentage of moonfish (genderwise) in different length classes, landed in trawl where, $\mathrm{L}_{\infty}$ is the asymptotic length, $\mathrm{K}$ is the von Bertalanffy growth coefficient i.e., the growth rate at which asymptotic length is attained (per year), Lt is the length of the fish at age ' $t$ ' and $t_{0}$ is the age of the fish at zero length. Longevity or maximal age $\left(\mathrm{t}_{\max }\right)$ of moonfish was estimated using the Pauly's equation (Pauly, 1983): $\mathrm{t}_{\max }=\mathrm{t}_{\mathrm{o}}+2.996 / \mathrm{K}$ and the ' $\mathrm{t}_{0}$ ' was estimated using the empirical equation proposed by Pauly (1979): $\log _{10}\left(-\mathrm{t}_{0}\right)=-0.392-0.275 \log _{10} \mathrm{~L}_{\infty}-1.038 \mathrm{~K}$. The growth performance index $(\varphi)$ was estimated as: $\varphi=\log _{10} K+2$ $\log _{10} \mathrm{~L}_{\infty}$ (Munro and Pauly, 1983), and compared with the results obtained for this species from other parts of the world.

The length-weight equations derived for males, females and indeterminates of $M$. maculata are given in Table 1. Analysis of covariance revealed no significant difference between male and female while there was significant difference with indeterminates. Hence the length-weight data of both sexes were pooled for further analysis.

Growth in an ideal fish is considered isometric if the weight of the fish is an exponential function of its length and the relationship could be expressed by the cube-law, i.e., weight $=\mathrm{a} \times$ length $^{3}$. The regression coefficient (b) of M. maculata was found to be 3.390 which differed significantly from the hypothetical isometric value (3), indicating positive allometric growth. Positive allometric growth was observed in males (3.316) and females (3.440) while the sex indeterminates with the $b$ value of 2.905 showed negative allometric growth. The male and female fishes grew faster in weight than in length while indeterminates grew faster in length than in weight (Fig 3a-c).

The comparison of length-weight studies conducted in moonfish across different seas around the world is shown in Table 2. The length-weight relationships of moonfish in the current study have shown major deviation in the ' $b$ ' values obtained from the previous studies. The present study has shown a positive allometric growth in case of adult fishes and a negative allometry in the case of indeterminates. These variations in growth among the indeterminates (mainly juveniles) and adults indicated that the fish grows more in length in the early phase and after a particular age, the increment in weight is more rapid than

Table 1. The length-weight equations derived for males, females and sex indeterminates of Mene maculata

\begin{tabular}{llll}
\hline Group & $\mathrm{L}-\mathrm{W}$ equation & $\mathrm{R}$ value & 'b'value \\
\hline Male & $\mathrm{W}=0.00629 \mathrm{~L}^{3.316}$ & 0.98 & 3.316 \\
Female & $\mathrm{W}=0.00465 \mathrm{~L}^{3.440}$ & 0.99 & 3.440 \\
Pooled data & $\mathrm{W}=0.00524 \mathrm{~L}^{3.390}$ & 0.97 & 3.390 \\
Sex indeterminates & $\mathrm{W}=0.02330 \mathrm{~L}^{2.905}$ & 0.98 & 2.905 \\
\hline
\end{tabular}




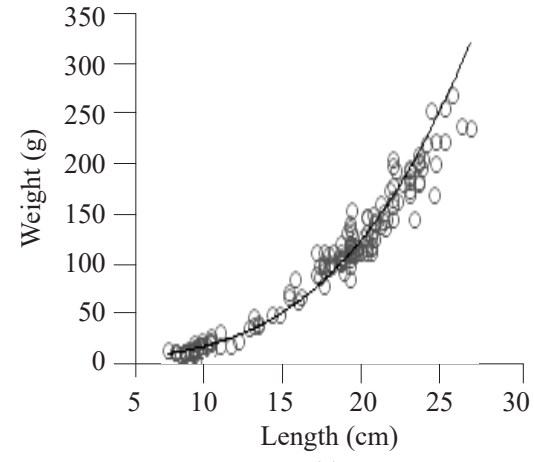

(a)

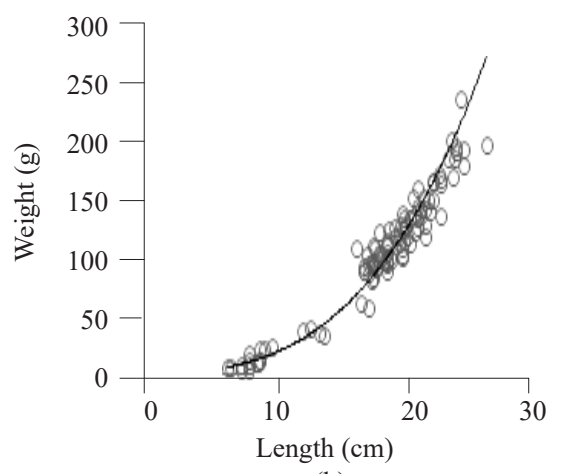

(b)

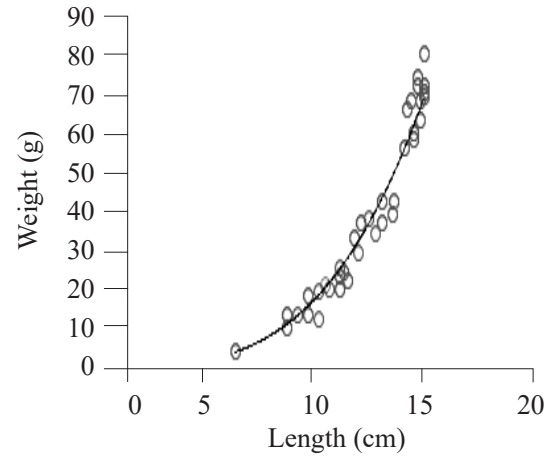

(c)

Fig. 3. Length-weight relationship of moonfish a) Female; b) Male; c) Sex indeterminates

Table 2. Comparison of length-weight studies conducted on moonfish across different seas around the world

\begin{tabular}{|c|c|c|c|c|c|c|c|c|}
\hline $\mathrm{a}$ & $\mathrm{b}$ & Sex & $\begin{array}{l}\text { Sample } \\
\text { size }\end{array}$ & $\begin{array}{l}\text { Length } \\
(\mathrm{cm})\end{array}$ & $\begin{array}{l}\text { Length } \\
\text { type }\end{array}$ & $r^{2}$ & Locality & Reference \\
\hline 0.0344 & 2.939 & Unsexed & 150 & $10.0-21.0$ & SL & 0.955 & $\begin{array}{l}\text { South-western waters, } \\
\text { Taiwan, 1981-84 }\end{array}$ & Hwang et al. (2002) \\
\hline 0.0153 & 3 & Unsexed & 5 & $10.2-15.5$ & $\mathrm{TL}$ & - & - & Paulyet al. (1998) \\
\hline 0.0229 & 3 & Unsexed & 5 & $9.0-13.0$ & SL & - & - & Paulyet al. (1998) \\
\hline 0.0219 & 3.147 & Unsexed & 154 & $11.0-20.0$ & SL & 0.994 & $\begin{array}{l}\text { South-western waters, } \\
\text { Taiwan, 1995-97 }\end{array}$ & Hwang et al. (2002) \\
\hline 0.0234 & 3.186 & unsexed & 30 & $7.2-17.5$ & SL & 0.995 & $\begin{array}{l}\text { Davao Gulf, Phillipines, } \\
\text { 2009-12 }\end{array}$ & Gumanao et al. (2016) \\
\hline 0.00006 & 2.842 & unsexed & 1025 & $8.3-25.6$ & FL & 0.94 & $\begin{array}{l}\text { Beibu Gulf, South China } \\
\text { Sea, 2011-12 }\end{array}$ & $\begin{array}{l}\text { DU Shi-qiang et al. } \\
\text { (2012) }\end{array}$ \\
\hline 0.0046 & 3.440 & Female & 153 & $7.5-25.5$ & $\mathrm{TL}$ & 0.98 & $\begin{array}{l}\text { Eastern Arabian Sea } \\
\text { off Karnataka Coast }\end{array}$ & Present study \\
\hline 0.00629 & 3.316 & Male & 105 & $7-25.6$ & $\mathrm{TL}$ & 0.96 & $\begin{array}{l}\text { Eastern Arabian Sea } \\
\text { off Karnataka Coast }\end{array}$ & Present study \\
\hline 0.0233 & 2.905 & $\begin{array}{l}\text { sex } \\
\text { indeterminates }\end{array}$ & 81 & $6-15$ & $\mathrm{TL}$ & 0.96 & $\begin{array}{l}\text { Eastern Arabian Sea } \\
\text { off Karnataka Coast }\end{array}$ & Present study \\
\hline
\end{tabular}

SL - Standard length; TL - Total length

the increment in length resulting in a changeover from negative allometry to a positive allometry. The differences seen in the 'b' value estimated in the present study and that carried out by earlier researchers could be due to the difference in sampling techniques or due to the varying environmental and ecological parameters prevailing in different ecosystems. The regional differences in the growth and maturation of the fish could also lead to difference in the growth pattern (Ahmed et al., 2011).

The growth parameter estimates for M. maculata, derived in the present study, employing different methods in FiSAT II are given in Table 3. In order to estimate the length of fish at different age, $L_{\infty}$ value of $29.1 \mathrm{~cm}, \mathrm{~K}$ value of $1.014 \mathrm{yr}^{-1}$ and $\mathrm{t}_{0}$ of -0.014 were used, as the r-values (0.38) were good. The average length attained by moonfish at different age is given in Table 4. Maximum size of the fish obtained during the study was $25.5 \mathrm{~cm}$. This corresponds to approximately 2 years of age and could be considered as the maximum fishable life span of moonfish fished off Karnataka waters. The $\mathrm{t}_{\max }$ for the fish was estimated as 2.97 years which is approximately 3 years of age. The estimated value of $\mathrm{L}_{\infty}$ in the present study falls well within the range of $21.8-33.4 \mathrm{~cm}$ as observed in the past studies

Table 3. Growth parameters estimated for M. maculata, using different methods in FiSAT II

\begin{tabular}{lll}
\hline Method used & $\mathrm{L}_{\infty}(\mathrm{cm})$ & $\mathrm{K}\left(\mathrm{yr}^{-1}\right)$ \\
\hline Modified Wetherall plot & 28.14 & - \\
ELEFAN I & 29.10 & 1 \\
$\begin{array}{l}\text { Bhattacharya and G\&H plot } \\
\text { (before gear selection) }\end{array}$ & 28.24 & 1.14 \\
$\begin{array}{l}\text { Bhattacharya and G\&H plot } \\
\text { (After correction for gear selection) }\end{array}$ & 29.10 & 1.014 \\
\hline
\end{tabular}

Table 4. Age-length key for moonfish, off Karnataka waters

\begin{tabular}{llllll}
\hline Age & $0.5 \mathrm{yr}$ & $1 \mathrm{yr}$ & $1.5 \mathrm{yr}$ & $2 \mathrm{yr}$ & $2.5 \mathrm{yr}$ \\
\hline Length $(\mathrm{cm})$ & 11.8 & 18.69 & 22.83 & 25.32 & 26.82 \\
\hline
\end{tabular}


(Table 5). The growth parameters estimated were found to be different from the estimates made by Hwang et al. (2002), while similar to those by Armada (2004). The growth performance index $(\varphi)$ of the fish in the present study estimated at 2.934 , is comparable with values obtained in other studies (2.13 to 2.87) indicating that the growth parameters estimated are reliable. The difference in the $\varphi$ value may be due to impact of variation in the environmental parameters and geographical variation of the sampling sites.

Table 5. Comparison of growth parameter studies conducted in moonfish across different seas around the world

\begin{tabular}{|c|c|c|c|c|c|c|c|}
\hline $\mathrm{L}_{\infty}$ & Length type & $\mathrm{K}\left(\mathrm{yr}^{-1}\right)$ & $\varphi$ & $t_{0}$ & $\mathrm{~L}_{\max }$ & Country/Locality & Reference \\
\hline 21.8 & $\mathrm{SL}$ & 0.285 & 2.13 & - & 21 & South western waters, Taiwan & Hwang et al. (2002) \\
\hline 22.5 & TL & 1.22 & 2.79 & - & 21.4 & Manila Bay, Philippines & Ingles and Pauly (1984) \\
\hline 26 & - & 1.1 & 2.87 & 1.98 & - & Davao Bay, Philippines & Armada (2004) \\
\hline 28 & $\mathrm{SL}$ & 0.186 & 2.16 & - & 20 & South western waters, Taiwan & Hwang et al. (2002) \\
\hline 33.49 & FL & 0.17 & 2.28 & -0.92 & 25.6 & Beibu Gulf, South China Sea & DU Shi-qiang et al. (2012) \\
\hline 29.1 & TL & 1.014 & 2.934 & -0.014 & 25.5 & Eastern Arabian Sea, India & Present Study \\
\hline
\end{tabular}

SL - Standard length; TL - Total length

\section{Acknowledgements}

The authors are grateful to the Director, ICAR-CMFRI, Kochi for providing facilities to carry out the study. The first author thanks Captain Jayaprakash Mendon for providing samples for the study.

\section{References}

Ahmed Egbal, O., Mohammed Ali, E. and Afra Aziz, A. 2011. Length-weight relationships and condition factors of six fish species in Atbara River and Khashm el-Girba Reservoir, Sudan. Int. J. Agri. Sci., 3(1): 65-70.

Armada, N. B. 2004. Fish resource assessment and management recommendations for Davao Gulf. In turbulent seas: The status of Philippine marine fisheries. Coastal Resource Management Project, DA-BFAR, Philippines, p. 332-335.

Du Shi-Qiang, Feng Bo, Hou Gang, Lu Huo-Sheng and Yan YunRong 2012. Age and growth of moonfish, Mene maculata from mouth of the Beibu Gulf, South China Sea. J. Fish. China, 4: 576-583

Edwards, A. L. 1976. An introduction to linear regression and correlation. W. H. Freeman and Company, USA, 213 pp.

Gayanilo, F. C. Jr., Sparre, P. and Pauly, D. 1996. The FAOICLARM Stock Assessment Tools (FiSAT). User's Manual. Food and Agriculture Organiszation of the United Nations, Rome, 124 pp.

Gulland, J. A and Holt, S. J. 1959. Estimation of growth parameters for data at unequal time intervals. J. Cons. CIEM, 25: 47-49.

Gumanao, G. S., Saceda-Cardoza, M. M., Mueller, B. and Bos, A. R. 2016. Length-weight and length-length relationships of 139 Indo-Pacific fish species (Teleostei) from the Davao Gulf, Philippines. J. Appl. Ichthyol., 332: 377-385.

Hwang, S.-Y., Chen, C.-T and Liu, K. M. 2002. Age and growth of the moon fish Mene maculata, before and after heavy exploitation in south-western Taiwan waters. J. Fish. Soc. Taiwan, 29(4): 299-311.

Ingles, J. and Pauly, D. 1984. An atlas of the growth, mortality and recruitment of Philippines fishes. ICLARM Tech. Rep., 13: $127 \mathrm{pp}$.

Kapoor, D., Dayal, R. and Ponniah, A. G. 2002. Fish biodiversity of India. National Bureau of Fish Genetic Resources Lucknow, India, 775 pp.

Le Cren, C. D. 1951. Length-weight relationship and seasonal cycle in gonad weights and condition in the perch (Perca fluviatilis). J. Anim. Ecol., 20: 201-219.

Mohamed, K. S. and Syda Rao, G. 1997. Seasonal growth, stock-recruitment relationship and predictive yield of the Indian squid Loligo duvauceli (Orbigny) exploited off Karnataka coast. Indian J. Fish., 44(4): 319-329.

Munro, J. L. and Pauly, D. 1983. A simple method for comparing the growth of fishes and invertebrates. Fishbyte, 1: 5-6.

Pauly, D. 1983. Length converted catch curves. A powerful tool for fisheries research in the tropics (Part 1). ICLARM Fishbyte, 1: $325 \mathrm{pp}$.

Pauly, D., Froese, R. and Albert, J. S. 1998. The BRAINS table. In: Froese, R. and Pauly, D. (Eds.), FishBase, 98: concepts, design and data sources. ICLARM, Manila, Philippines, p. 195-198.

Rajan, P. T., Sreeraj, C. R. and Immanuel, T. 2011. Fish fauna of coral reef, mangrove, freshwater, offshore and seagrass beds of Andaman and Nicobar Islands. Zoological Survey of India, Andaman and Nicobar Regional Centre, Haddo, Port Blair, $432 \mathrm{pp}$.

Snedecor, G. W. and Cochran, W. G. 1967. Statistical methods. The Iowa State University Press, Ames, Iowa, 45 pp. 
Sparre, P. and Venema, S. C. 1998. Introduction to tropical fish stock assessment-Part 1. Food and Agriculture Organisation of the United Nations, Rome, 407 pp.
Talwar, P. K. and Kacker, R. K. 1984. Commercial sea fishes of India. Zoological Survey of India, Calcutta, 997 pp. 